\author{
مقاله بزوهشى \\ مجله دانشگاه علوم يزشكى رفسنجان

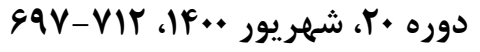

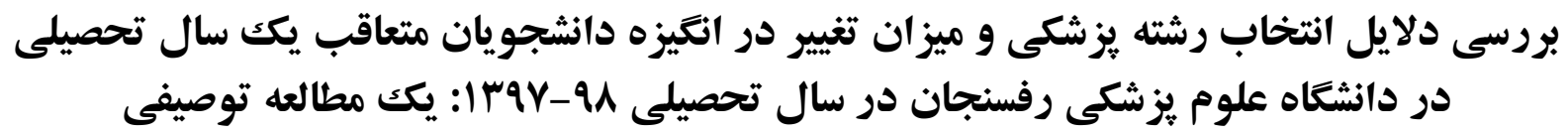

كيميا دامغانى '، حسن احمدى نيا'، محسن رضائيان

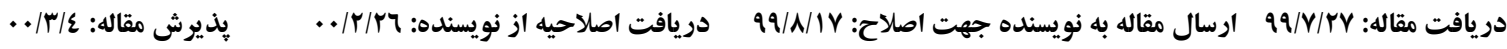

جكيده

زمينه و هدف: انكَيزه دانشجويان يزشكى از انتخاب اين رشته، نقش مهمى بر عملكرد آنها به عنوان كادر درمان آينده دارد. هدف از انجام اين مطالعه، تعيين دلايل انتخاب رشته يزشكى و ميزان تغيير در انخَيزه دانشجويان متعاقب يك سال تحصيلى در دانشخاه علوم يزشكى رفسنجان در سال تحصيلى

مواد و روشها: اين مطالعه توصيفى طى دو مرحله و به فاصلهى يك سال انجام شد. جمعيت مورد مطالعه شامل كليه دانشجويان يزشكى دانشًاه علوم يزشكى رفسنجان بود كه هم در سال تحصيلى

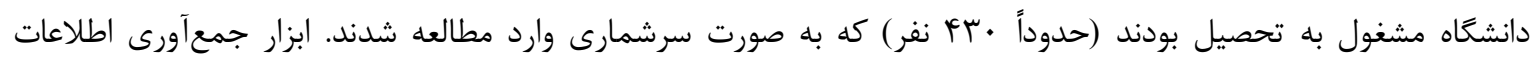

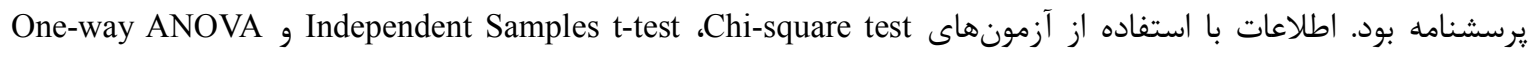
آناليز شدند.

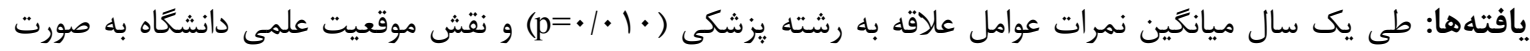

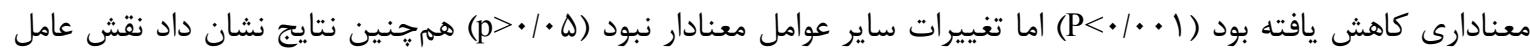

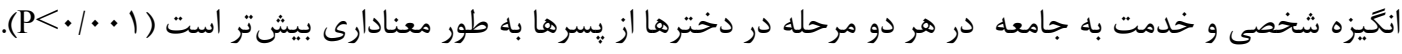

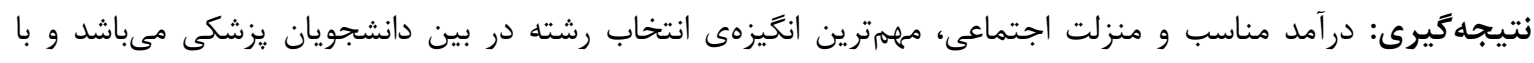

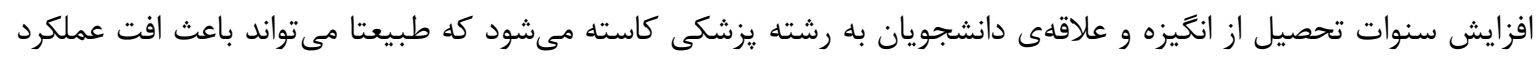
آنها شود و بايد به عنوان زنت خطرى براى مسئولين بهداشت و درمان در نظر كرفته شود.

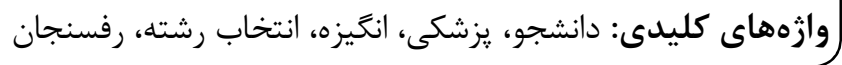

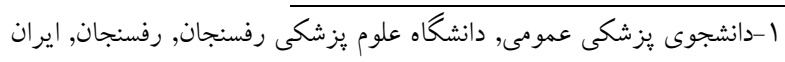

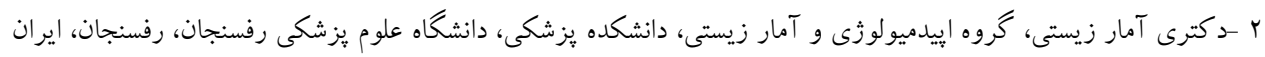

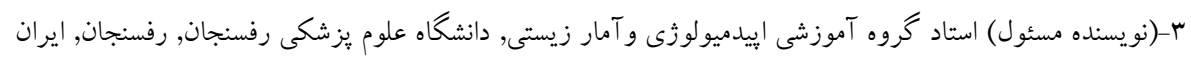

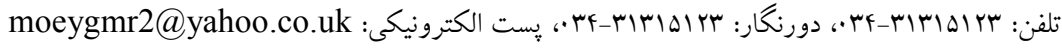


19 بروسى دلايل انتخاب رشته يزشكى و ميزان تغيير در انخيزه دانشجويان متعاقب يك سال تحصيلى ...

شوند. انكيزههاى درونى، به علايق خود فرد بر مى گردد و

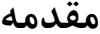
عوامل خارجى در آن نقش ندارند و اما انخيزههاى بيرونى، تحت تأثير عوامل خارجى هستند [V]. هر نقص در عامل ذهنى انكَيزه، در بعد انديشه منجربه مشكلات اصلى در ابعاد مختلف احساسات و رفتار و در نتيجه بدبينى، استرس و حتى افسردىى و همجنين افت شديد در عملكردهاى شخصى، اجتماعى و حرفهاى مىشود [ᄉ]. يروهشهاى متعددى در كشورهاى مختلف در رابطه با عوامل و انخَيزهاى مؤثر بر انتخاب رشته يزشكى انجام شده است و در بيشتر اين مطالعات، عواملى همجِون خدمت به مردم جامعه، منزلت اجتماعى و درآمد مناسب از رايجترين عللى بودهاند كه دانشجويان يزشكى به آنها اهميت مىدهند

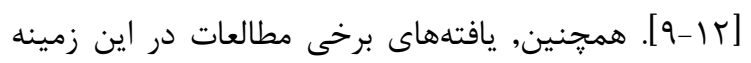
نشان مىدهند كه اگرجه دانشجويان در بدو ورود به دانشعاه با علاقه رشته يزشكى را انتخاب مى كنند، اما با افزايش سنوات تحصيل، از ميزان علاقه و انكَيزه آنان به تحصيل در اين رشته، كاسته مىشود. فشرده بودن برنامه درسى، مشكلات آموزشى در مقطع بالينى و نكرانى از آينده شغلى، از عوامل مؤثر در اين ارتباط بودهاند [ها-با I] بنابر آنجه كَفته شد، لزوم انجام مطالعات ملى و منطقهاى درباره عوامل مؤثر بر انخيزه دانشجويان يزشكى آشكار مى شود كه مىتواند ضمن كمك به مديران نظام سلامت در تربيت تزشكان متعهد و سياست كذارى برنامهاى كلان سلامت، در ارتقاء سلامت آحاد مردم جامعه نير مؤثر باشد. لذا اين مطالعه با هدف تعيين دلايل انتخاب رشته يزشكى و

هر سازمان براى رسيدن به اهداف خود احتياج به منابع مختلفى دارد. بدون شك, مههمرين منبع هر سازمان، نيروى انسانى شاغل در آن است. جنانجه اين نيرو داراى انخَيزه، رقابت شغلى و روحيه مناسب باشد، تمامى توان، استعداد و مهارت خود را در سازمان به كار خواهد كرفت. فوايد اين امر هم به خود شخص و هم به سازمان بر مى گردد؛ لذا موفقيت و پيشرفت هر سازمان به نيروى انسانى آن بستخى دارد [1] و نيروى انسانى با انكيزه، براى انجام وظايف، اساسىترين عامل بهرهورى است [ץ]. بر همين اساس، در سيسته بهداشت و درمان توجه به عوامل مؤثر بر انخيزه دانشجويان يزشكى به عنوان كادر درمان آينده و نيروى تأثيركذار بر

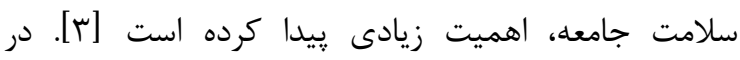
دانشخاههاى معتبر، اين عوامل در برنامهريزىها در نظر كرفته مىشود [F]. سالهاى طولانى است كه در ايران، رشتهى يزشكى اولين اولويت انتخاب رشته دانشآموزان داوطلب در كروه تجربى مىباشد. در بسيارى از ديخر كشورها نيز دانشآموزان ممتاز، در رشته يزشكى ادامه تحصيل مىدهند [ه]]. در كشور ما، انتخاب رشته دانشخاهى در سنين "ايين صورت مى مورد خصوصيات فراشناختى ضرورى در اين افراد در هنعام كزينش دانشجو انجام نمىشود. انگَيزه، به مجموعه عواملى اطلاق مىشود كه انسان را به فعاليت و حركت به سوى هدف وا مى دارد و به رفتار، نيرو جهت مى دهد [ع]. به طور كلى، انخيزهها به دو دسته بيرونى و درونى تقسيم بندى مى- 
انتخاب رشته دانشجويان رشتهى يزشكى طراحى شده بود، روايى صورى يرسشنامه توسط كارشناسان مورد بررسى و تأييد قرار گرفته است. همجنين روايى سازه يرسشنامه نيز با استفاده از تحليل عاملى تأييدى بررسى شده كه مشخص كَريد. ه عامل اين يرسشنامه \& \& • از واريانس كل را تبيين مى كنند. پايايى آن نيز با ضريب آلفاى كرونباخ برابر با \& AF| . تعيين شده است، در مطالعه حاضر نيز ضريب آلفاى كرونباخ براى اين گرسشنامه برابر با سو/• به دست آمد. يرسشنامه شامل r T سؤل نكرشسنجى مىباشد كه با توجه به محتواى سؤالات در ينج عامل شامل انخيزه شخصى و خدمت

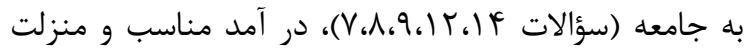

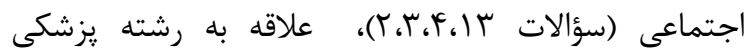

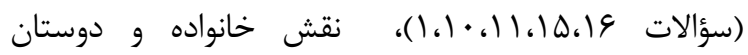

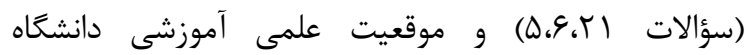

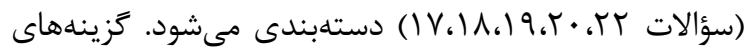
سؤالات يرسشنامه به صورت ينج درجهاى ليكرت از خيلى زياد تا بىاهميت با اختصاص نمره به ترتيب f تاصفر بود. در نهايت نمره هر عامل از ميانخين نمرهى سؤالات مربوط به آن به دست آمد و با توجه به اين كه تعداد سؤالات مربوط به همه عوامل با هم برابر نيست، جهت امكان مقايسه بهتر نمره هر عامل از . 1. محاسبه گرديد. مشخصات دموگرافيك شامل جنس، سن، سال ورود به دانشگاه، مقطع تحصيلى، محل سكونت، تحصيلات والدين و درآمد ماهيانه خانوار در

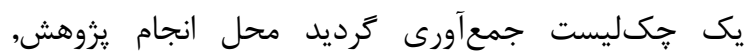

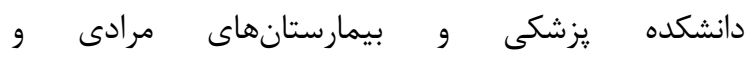

ميزان تغيير در انخيزه دانشجويان متعاقب يك سال تحصيلى در دانشگاه علوم يزشكى رفسنجان در سال تحصيلى 91-

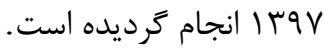

\section{مواد و روشها}

اين مطالعه، از نوع توصيفى مقطعى بود. جمعيت مورد مطالعه شامل كليه دانشجويان يزشكى شاغل به تحصيل در دانشعاه علوم يزشكى رفسنجان بود كه در هر دو سال تحصيلى تحصيل بودند (تقريباً • بَ نفر). اين مطالعه داراى كد اخلاق از دانشعاه علوم يزشكى رفسنجان به شماره ثبتى IR.RUMS.REC.1397.249 مىباشد. نمونه مورد بررسى, كليه دانشجويان مقاطع علوم پايه، فيزيوپاتولوزى، كارآموزى و كارورزى, كه هم در سال تحصيلى

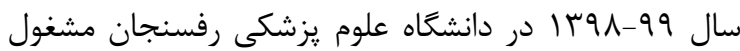
به تحصيل بودند به تعداد • نV نفر در مرحله اول و YF نفر در مرحله دوم كه به صورت داوطلبانه وارد مطالعه شدند.

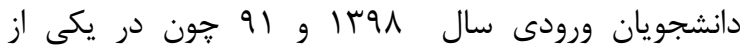
مراحل جمعآورى اطلاعات حضور نداشتند، از مطالعه حذف شدند. معيارهاى ورود به مطالعه شامل، دانشجوى رشته يزشكى در دانشخاه علوم يزشكى رفسنجان و عدم ابتلاء به اختلالات روانيزشكى مثل افسردگى و اضطراب بودند و افرادى كه اطلاعات آنها به صورت ناقص ثبت شده بود، از مطالعه حذف گرديدند. ابزار جمعآورى اطلاعات, پرسشنامه اى است كه قبلاً توسط Shakornia و همكاران [IT] جهت بررسى انخيزه 
. بر V. . . . . . .

آزمونهاى One-way ANOVA و Independent Samples ج-test دموكرافيك از جمله جنسيت استفاده شد. سطح معنىدارى در تمام آزمونها كمتر از هـ • • در نظر كرفته شد.

نتايج از مجموع · · نفر جامعه آمارى، در مرحله اول • نفر در مطالعه شركت كردند (درصد شركت كنندهها GT/A درصد) كه شامل درصد) بودند. و از اين تعداد س/T درصد در مقطع علوم

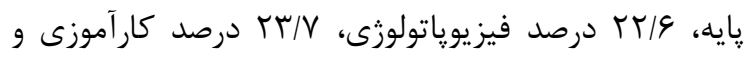

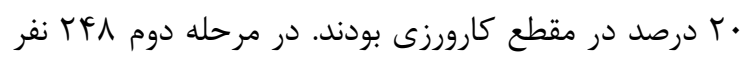
اقدام به تكميل يرسشنامه كردند (درصد شركت كنندهها QV/\& درصد) كه از اين تعداد צه نفر يسر (یז درصد) بودند كه به طور كلى توزيع فراوانى جنسيت در دو مرحله اول و دوم يكسان بود (P (P=/T). اما در مرحله دوم جامعه آمارى از نظر مقطع تحصيلى تغييرات معنى دار داشته و از دانشجويان مقطع علوم پايه كاسته شده و به دانشجويان مقطع كاروزى افزوده شده است كه به علت تغيير مقطع دانشحويان در سال دوم مىباشد. در هر دو مرحله به طور تقريبى 4 درصد دانشجويان بومى استان كرمان بودند و بالاى له درصد دانشجويان والدين با تحصيلات بيشتر از دييلمم داشتند. در جدول ا توزيع فراوانى تمام اطلاعات دموگرافيك دانشجويان در دو مرحله كزارش و مورد مقايسه قرار حرفته است.
علىابنابىطالب(ع) و زايشعاه نيكنفس شهر رفسنجان بود. در مرحله اول جمعآورى دادهها (اسفند 9V) پرسشنامهها سر كلاس درس ضمن هماهنگى با اساتيد و بعد از توضيح اهداف مطالعه و جلب همكارى دانشجويان در اختيار آنان قرار گرفت و بلافاصله بعد از تكميل، گردآورى شد. براى مراعات نكات اخلاقى به دانشجويان اين اجازه داده شد كه به طور داوطلبانه در اين تحقيق شركت كنند. جهت تكميل يرسشنامه توسط اينترنها, مجرى با حضور در بخشهاى بالينى و درمانگاهها يرسشنامهها را در اختيار آنان قرار داد تا

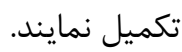
مرحلهى دوم جمعآورى دادهها طبق برنامه مىبايست در اسفند 19ז| و به صورت حضورى انجام شود، اما به علت شيوع ويروس كرونا در اسفندماه و تعطيلى دانشگاه، يرسشنامهها در بهار وجسا به صورت آنلاين در اختيار كليه دانشجويان زيشكى شاغل به تحصيل در دانشخاه علوم يزشكى رفسنجان (به جز ورودى ^هץ|) قرار گرفت تا مجدداً آنها را تكميل نمايند. دادهها يس از جمعآورى با استفاده از نرمافزار آمارى SPSS نسخه Fr مورد تجزيه و تحليل قرار گرفت. با استفاده از آزمون مجذور كاى، توزيع فراوانى متغيرها در دو مرحله مورد مقايسه قرار كرفت و از روشهاى آمار توصيفى (ميانگين، معدل، انحراف معيار و توزيع فراوانى) براى توصيف دادها و جهت تجزيه و تحليل دادهها، نمره هر كدام از عوامل مؤثر بر انتخاب رشته يزشكى محاسبه شد و با توجه به برقرار بودن فرض نرماليتى، از 
جلدول ا - مقا يسهى توزيع فروانى اطلاعات دموكرافيك دانشجويان در دومرحله جمع آورى اطلاعات

\begin{tabular}{|c|c|c|c|c|c|c|c|c|}
\hline \multirow{2}{*}{ مقدار P* } & \multicolumn{2}{|c|}{ مجموع } & \multicolumn{2}{|c|}{ 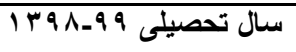 } & \multicolumn{2}{|c|}{ 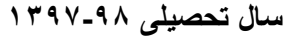 } & \multirow{2}{*}{ سطح } & \multirow{2}{*}{ متغير } \\
\hline & درصد & تعداد & درصد & تعداد & درصد & تعداد & & \\
\hline \multirow{2}{*}{ D } & $09 / 1$ & $r \cdot \tau$ & $7 / \pi$ & lor & ov & $10 \leqslant$ & دختر & \multirow{2}{*}{ جنسيت } \\
\hline & $\varepsilon \cdot / 9$ & rit & r^/ & 97 & $\varepsilon r$ & 117 & 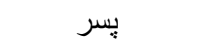 & \\
\hline \multirow{3}{*}{.1074} & $r Y / \varepsilon$ & 117 & $r \cdot / r$ & 01 & $r \leqslant / l$ & 70 & رفسنجان & \multirow{3}{*}{ سكونت } \\
\hline & $\leqslant 0 / 9$ & rra & $\varepsilon \wedge$ & 119 & $\varepsilon \varepsilon / 1$ & 119 & استان كرمان & \\
\hline & HI/V & $17 \varepsilon$ & TI/0 & $\vee \wedge$ & $r / 9$ & $\wedge \neg$ & ساير استانها & \\
\hline \multirow{3}{*}{$<\cdot / \cdots 1$} & $00 / 7$ & r^^ & $\varepsilon \tau / \varepsilon$ & 110 & $7 \leqslant / 1$ & IVT & خو ابحاه & \multirow{3}{*}{ سكونت فعلى } \\
\hline & $r \cdot / V$ & 109 & $r q / 1$ & $9 \vee$ & rt & Tr & منزل شخصى & \\
\hline & $I T / V$ & $v_{1}$ & $1 \leqslant / 0$ & ru & $1 T$ & ro & استيجارى & \\
\hline \multirow{6}{*}{$\cdot 1 \cdot 1 \leq$} & $\mid \wedge / 1$ & $9 \leq$ & $19 / 1$ & $\leqslant 9$ & $17 / V$ & $\leqslant 0$ & 94 & \multirow{6}{*}{ سال ورود } \\
\hline & $I Y / V$ & 77 & $1 r / 9$ & rt & $1 T / 4$ & $r \varepsilon$ & 94 & \\
\hline & $11 / 1$ & 71 & $1 r / 0$ & M & $11 / 1$ & $r$. & $9 \leq$ & \\
\hline & $19 / 1$ & 99 & $10 / \pi$ & rᄉ & $T r / T$ & 71 & 90 & \\
\hline & $19 / 9$ & $1 \cdot r$ & $r \varepsilon / r$ & 7. & $10 / 9$ & $\varepsilon r$ & 97 & \\
\hline & $17 / 7$ & $\wedge 7$ & $10 / \pi$ & rᄉ & $I V / \Lambda$ & $\varepsilon \Lambda$ & $9 \vee$ & \\
\hline \multirow{4}{*}{$<\cdot 1 \cdots$} & $r \varepsilon / 9$ & 149 & $10 / \pi$ & rᄉ & TT/V & 91 & علوم بِايه & \multirow{4}{*}{ مقطع } \\
\hline & $r \leqslant / 0$ & ITV & $r T / \tau$ & 77 & $r r / T$ & 7 & فيزيوياتولوزى & \\
\hline & $r \leqslant / V$ & IrA & ro/A & $7 \leq$ & $r M / V$ & $7 \leq$ & استاجرى & \\
\hline & $r 0 / 9$ & $1 T \varepsilon$ & $r r / r$ & $\wedge$. & $r$. & $0 \leqslant$ & اينترنى & \\
\hline \multirow{5}{*}{$\cdot / r 91$} & TI/0 & אוד & $\mathrm{To/}$ & $\wedge \wedge$ & $r V / \Lambda$ & vo & دييلم وكمتر & \multirow{5}{*}{ تحصيلات يدر } \\
\hline & 11 & ov & $1 \cdot 10$ & $r y$ & $11 / 0$ & M & فوق دييلم & \\
\hline & Tr/s & IVT & $r \cdot / r$ & vo & 酒 & $9 \wedge$ & ليسانس & \\
\hline & $10 / \varepsilon$ & $\wedge$. & $1 \leqslant / 9$ & rv & $10 / 9$ & $\varepsilon r$ & فوق ليسانس & \\
\hline & $\Lambda / \mu$ & $\varepsilon r$ & $1 / 9$ & rr & $\mathrm{V} / \mathrm{A}$ & r) & دكترى و بالاتر & \\
\hline \multirow{5}{*}{.1019} & $r \varepsilon / r$ & IVV & $r q / V$ & 91 & $r 1 / 9$ & $\wedge T$ & ديليلم وكمتر & \multirow{5}{*}{ تحصيلات مادر } \\
\hline & $11 / 4$ & $0 \wedge$ & $11 / r$ & $r \wedge$ & $11 / 1$ & $r$. & فوق دييلم & \\
\hline & $\varepsilon 1 / 0$ & Y10 & $\varepsilon \cdot / \mu$ & $1 \ldots$ & $\leqslant r / T$ & 110 & ليسانس & \\
\hline & $1 \cdot 11$ & 07 & $1 \cdot 10$ & YY & $11 / 1$ & $r$. & فوق ليسانس & \\
\hline & $1 / 9$ & 1. & $1 / r$ & r & $r / T$ & v & دكترى و بالاتر & \\
\hline \multirow{4}{*}{$<\cdot / \cdot \cdot 1$} & 9 & $\leqslant 7$ & $7 / 1$ & 10 & $11 / 0$ & r & زير r ميليون & \multirow{4}{*}{ 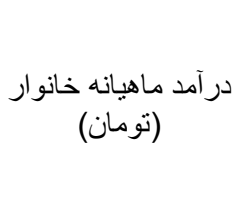 } \\
\hline & $\leqslant 7$ & דצזי & $r \wedge / q$ & 90 & $O Y / \varepsilon$ & $1 \leq 1$ & r تا ه ميليون & \\
\hline & $r / / r$ & 17. & $\Gamma \wedge / q$ & 90 & $r \leqslant / r$ & 70 & ه تا. ا ميليون & \\
\hline & $1 \pi / \Lambda$ & VI & 17 & rq & $11 / 9$ & rr & بالاى · ا ميليون & \\
\hline
\end{tabular}




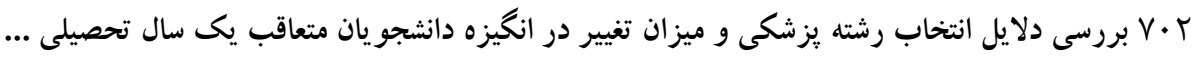

علمى دانشگاه (نمودار (1). سيس با استفاده از آزمون مستقل نمرات هر عامل در مرحله اول و دوم با هم مقايسه شدند كه عامل علاقه به رشته يزشكى به صورت معنىدارى

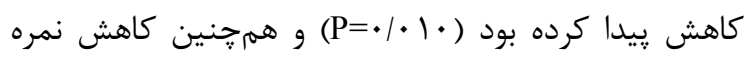
نقش موقعيت علمى دانشگاه معنى دارى بود ( ( P< (P)، اما تغييرات ساير عوامل معنى دار نبود (ه •/P>).
در ابتدا نمره هر يك از عوامل مؤثر بر انخيزه در هر دو مرحله تعيين شد كه بر اساس نتايج به دست آمده در هر دو مرحله بيشترين ميانگين نمره را عامل درآمد مناسب و منزلت اجتماعى داشته است و ترتيب ساير عوامل در هر دو مرحله اين گونه بود: انخيزه شخصى و خدمت به جامعه، نقش خانواده و دوستان، علاقه به رشته يزشكى، نقش موقعيت
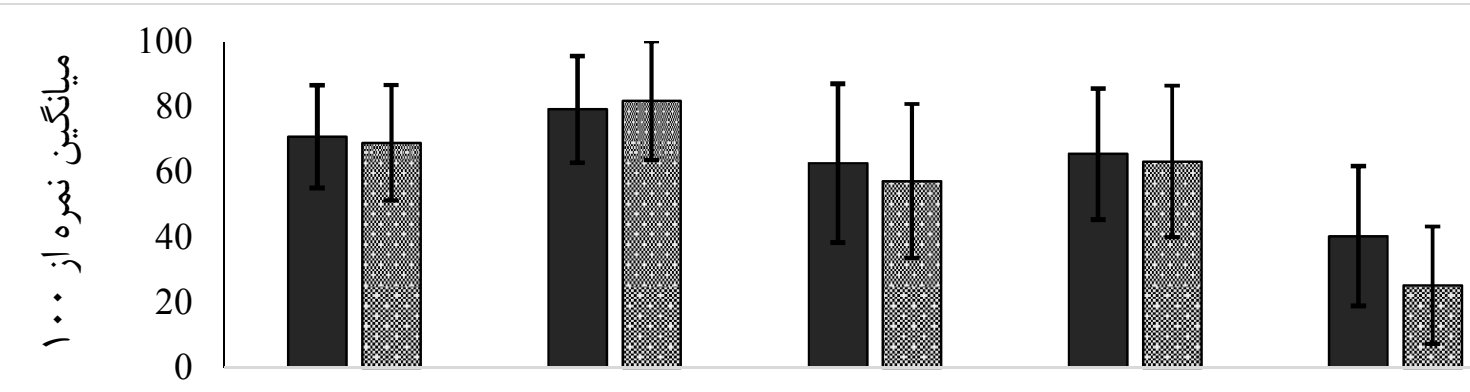

نقث موقيت علمى دانشخاه

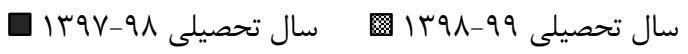

\section{نمودار ا - مقا يسه نمرهى هر يك از عوامل مؤثر بر انتكيزه در دو موحله در دانشجويان يزثكى دانشعاه علوم يزثكس رفسنجان}

در مرحله اول اندازهگيرى در دخترها بيشتر بود

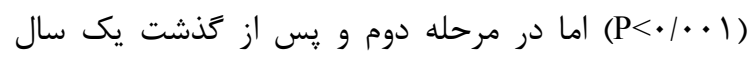
تحصيلى علاقه به رشته يزشكى در دخترها كاهش

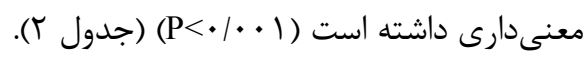

مقايسه بين عوامل مؤثر بر انخَيزه بر حسب جنسيت دانشجويان با استفاده از آزمون t مستقل انجام شد كه نشان داد نمرهى عامل انخيزه شخصى و خدمت به جامعه در هر دو مرحله به صورت معنى دارى در دخترها بيشتر مىباشد

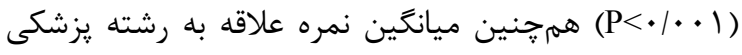


جدول r - مقا يسه ميانكين نمرات هر يك از عوامل انكيزه در دو مرحله اندازهكيرى برحسب جنسيت در دانشجويان بزشكس دانشكاه علوم بزشكى رفسنجان

\begin{tabular}{|c|c|c|c|c|c|c|}
\hline \multirow{2}{*}{ مقدار P" } & \multicolumn{2}{|c|}{ بسر (n=119) } & \multicolumn{2}{|c|}{ دختر (n= } & & \multirow[b]{2}{*}{ متغير } \\
\hline & انحر اف معيار & ميانغين & انحر اف معيار & 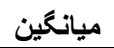 & & \\
\hline$<\cdot / \cdots)$ & $10 / \mu$ & $70 / 4$ & $1 \varepsilon / \wedge T$ & $V \leqslant / 9$ & سال تحصيلى 9V_q & \\
\hline \multirow[t]{2}{*}{$<\cdot / \cdots 1$} & $17 / 01$ & ז/ & $1 V / 77$ & $V Y / \varepsilon r$ & سال تحصيلى 9 9_ 9 ـ & انعيزه شخصى و خدمت به جامعه \\
\hline & \multicolumn{2}{|c|}{ 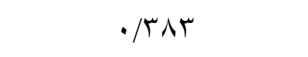 } & \multicolumn{2}{|c|}{$\cdot / \Lambda \wedge \vee$} & مقدار Pق & \\
\hline$\cdot / r q r$ & $\mid r / \Lambda \varepsilon$ & $\Lambda \cdot / r \wedge$ & $11 / \cdot r$ & $V \wedge / Y \varepsilon$ & سال تحصيلى १V_q^ & \\
\hline \multirow[t]{2}{*}{$\cdot / \varepsilon 19$} & $1 v / 19$ & N & $11 / \vee 9$ & $\wedge 1 / \cdot \Lambda$ & سال تحصيلى 9^_q & درآمد مناسب و منزلت اجتماعى \\
\hline & \multicolumn{2}{|c|}{$\cdot / r r$} & \multicolumn{2}{|c|}{.$/ 1 \vee 9$} & مقدار Pق & \\
\hline$<\cdot / \cdots 1$ & $r o / .0$ & $00 / 70$ & $r \varepsilon / V r$ & $T V / a r$ & سال تحصيلى 9V_q & \\
\hline \multirow[t]{2}{*}{$\cdot / V \leq r$} & $r) / 9$. & $07 / 71$ & YI/VV & ov/r & سال تحصيلى 91_9 & علاقه به رشته بٍزشكى \\
\hline & \multicolumn{2}{|c|}{.$/ 179$} & \multicolumn{2}{|c|}{$<\cdot / \cdots 1$} & مقدار P & \\
\hline$\cdot / r \leq \varepsilon$ & $|V / \varepsilon|$ & $T H / \Lambda \varepsilon$ & YI/VV & $r Y / V Y$ & سال تحصيلى 9V_q^ & \\
\hline \multirow[t]{2}{*}{$\cdot / \cdots v$} & $r(r)$ & $O N / T \leq$ & $r T / V \varepsilon$ & $77 / \% 9$ & سال تحصيلى 9^_ 9 & نقش خانواده و دوستان \\
\hline & \multicolumn{2}{|c|}{$\cdot / \cdot \Sigma V$} & \multicolumn{2}{|c|}{./^१४ } & مقدار P & \\
\hline \multirow{3}{*}{$\begin{array}{l}\cdot / 901 \\
. / 18 .\end{array}$} & 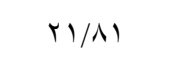 & $0 . / Y 4$ & rI/rT & $\varepsilon \cdot / \varepsilon r$ & سال تحصيلى 9V_q^ & \\
\hline & $I V / Y_{0}$ & r & $1 \wedge / \Gamma$. & $r \Psi / 0 \leq$ & سال تحصيلى 9^_9 & نقش موقعيت علمى دانشگاه \\
\hline & \multicolumn{2}{|c|}{$<\cdot / \cdots)$} & \multicolumn{2}{|c|}{$<\cdot 1 \cdots 1$} & مقدار P* & \\
\hline
\end{tabular}

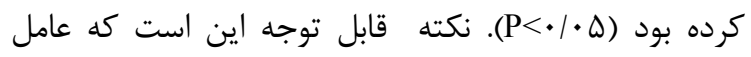
انخَيزه شخصى و همجنين علاقه به رشته يزشكى در هيج كدام از ورودىها با حذشت يك سال تغيير آمارى معنىدارى ييدا نكرده بودند اما با انجام آزمون آناليز واريانس يك طرفه جهت مقايسه نمرات ورودىهاى مختلف در يك مرحله متوجه شديم بين نمره ى علاقه به رشته يزشكى در ورودىهاى مختلف در هر دو مرحله تفاوت آمارى معنادارى وجود داشت ( ( • P< به اين صورت كه با افزايش سنوات تحصيل و بالاتر رفتن مقطع تحصيلى از علاقه به رشته يزشكى نيز كم مىشود. (جدول ؟)
با استفاده از آزمون t مستقل مقايسه ى بين نمرات عوامل مؤثر بر انخيزه در مرحله اول و دوم برحسب سال ورود دانشجويان انجام شد. نتايج نشان داد يس از گذشت يك سال، ميانگين نمره در آمد مناسب و منزلت اجتماعى در همه ورودىها (به جز ورودى هوبا) افزايش داشته كه اين افزايش فقط در ورودىهاى سqسا و و و ا معنىدار بوده

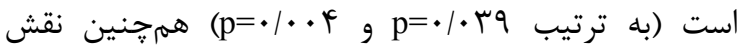
خانواده و دوستان تنها در ورودى VY I در مرحله دوم كاهش معنى دارى داشته است. نمره نقش موقعيت علمى دانشگاه از نظر همه ورودىها در مرحله دوم كاهش ييدا

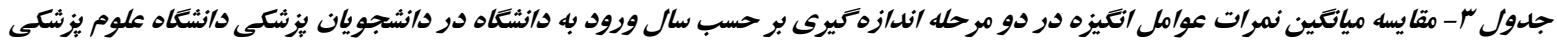
رفسنجان 
ץ. بررسى دلايل انتخاب رشته يزشكى و ميزان تغيير در انخگيزه دانشجويان متعاقب يك سال تحصيلى ...

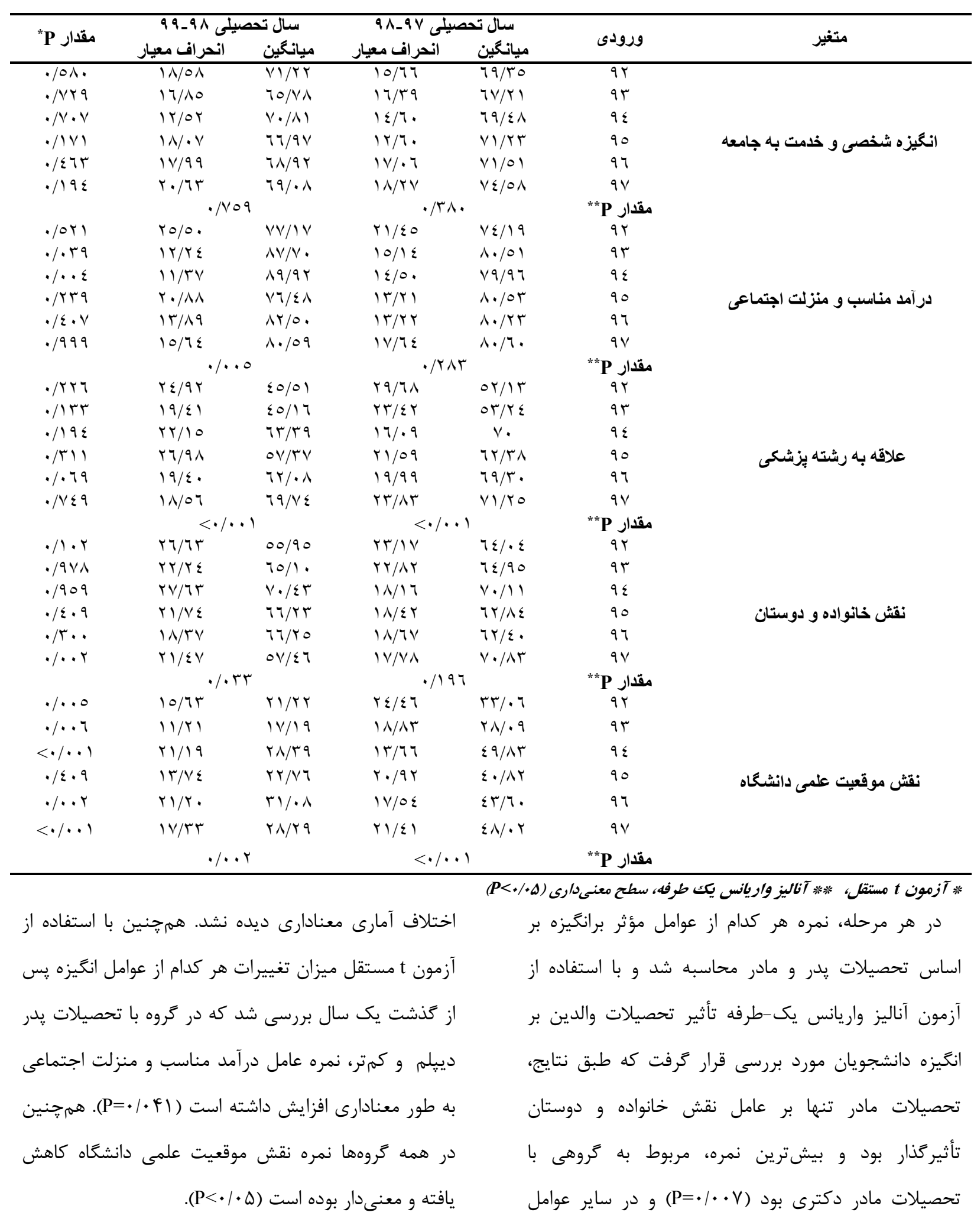


دانشجويان را بيشتر مى كند [19]. در مطالعه ى Crossely و همكاران، فرصت شغلى، جزء مههمرين معيارهاى انتخاب حرفه در بين دانشجويان يزشكى بوده است. [.r]. همجنين مطالعهاى در تركيه و همجنين مطالعهى Hamedi Rad در تبريز نشان دادند درآمد بالا مهمترين عامل انغيزه دانشجويان بزشكى بوده است كه با اين مطالعه همخوانى

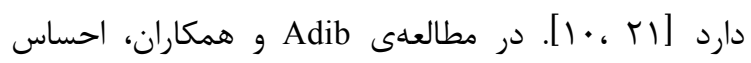
مفيد بودن و منزلت اجتماعى در ايجاد و حفظ علاقه به حرفه، تأثير بيشترى داشتند [Tr]. در مطالعهاى در نروز، دانشجويان برمنزلت اجتماعى و آسايش خاطر، تاكيد كردهاند

طبق نتايج اين مطالعه، عامل انكيزهى شخصى و خدمت به جامعه، در هر دو مرحله دومين عامل مؤثر در انتخاب رشتهى دانشجويان بوده است. همواره خدمت به مردم به عنوان يك امر مقدس و انسان دوستانه يكى از عوامل انخيزشى اشتغال در بخش بهداشتى و درمانى بوده است. از

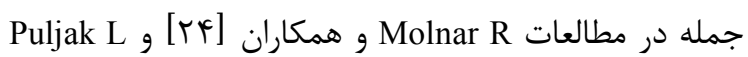

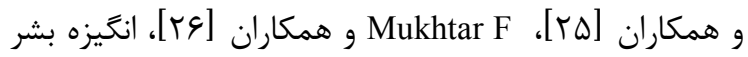
دوستانه را جزء فاكتورهاى اصلى براى انتخاب رشتهى يزشكى دانستند. براساس مطالعات انجام شده در آمريكا در سال 1991، بيشترين انخيزه در دانشجويان سال اول يزشكى، مراقبت از بيماران، ارتباط با بيماران، و در مجموع كمك به مردم بوده است [rV] در مطالعهاى در نرورة، نتايج مشابهى به دست آمده است و دانشجويان بر خدمت به جامعه تأكيد كردهاند [rr]. در مطالعهى crossley و همكاران، انخَيزهاى بشر دوستانه و كمك به ديخران،

اين مطالعه با هدف تعيين دلايل انتخاب رشته يزشكى و ميزان تغيير در انگَيزه دانشجويان متعاقب يك سال تحصيلى در دانشكاه علوم بزشكى رفسنجان در اسفند Vوبا و يك سال بعد از آن انجام شد. نتايج نشان داد از بين ه عامل بررسى شده دلايل انتخاب رشته دانشجويان يزشكى، درآهد مناسب و منزلت اجتماعى، اولين عامل مؤثر بر انتخاب رشتهى يزشكى در هر دو مرحله بوده است. بهطور كلى در انتخاب شغل دو عامل درآمد و منزلت اجتماعى نقش تعيين كننده دارند و از عواملى هستند كه در بيشتر مطالعات جزء مهمترين عوامل مؤثر در انتخاب رشته يزشكى گزارش شده اند. در مطالعهاى كه توسط مركز مطالعات سازمان سنجش انجام شده، مشخص گرديد كه انخَزهاى داوطلبان تهرانى براى ورود به دانشكاه به ترتيب اولويت عبارتند از: منزلت اجتماعى، محيط اجتماعى دانشاه، انگَيزى شغلى، علاقه تحصيلى بودند كه اين يافتهها با نتايج اين مطالعه كم و بيش همخوانى دارد [19]. Solas در تحقيقى بر روى دانشجويان روانشناسى نتيجه ترفت كه عوامل مالى و اقتصادى از مهمترين انخيزههاى دانشجويان به شمار مىرود زيرا اين عوامل به طور غيرمستقيم با نيازهاى اساسى آنها ارتباط دارد [IV]] به نظر مىرسد وضعيت مالى خوب، و داشتن شغل مناسب كه همگى جزء نيازهاى اساسى فيزيولوزيكى هستند، از مهمترين عوامل انگيزشى مىباشند [11]. نتايج برخى تحقيقات نشان مى مهند كه هرجه احتمال بيشترى براى دستيابى نيازهاى اساسى فرد در آينده وجود داشته باشد، انگيزه فعاليت زمان حاضر در 
צ• V. بررسى دلايل انتخاب رشته يزشكى و ميزان تغيير در انگيزه دانشجويان متعاقب يك سال تحصيلى ...

انغيزه تحصيلى ديده نشد [•r]. همرجنين در مطالعه Izadi و همكاران، سطح تحصيلات يدر و مادر، ارتباطى با انگيزه تحصيلى نداشت [بr] در مرحله دوم مطالعه نقش عامل خانواده و دوستان در انخيزهى دانشجويان سال اول [ورودى

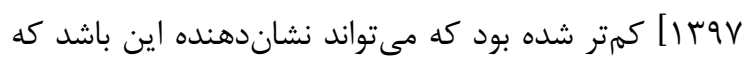
با افزايش سنوات تحصيل و افزايش شناخت دانشجويان از رشته تحصيلى، نقش خانواده در ادامه تحصيل در اين رشته كمرنتَتر مىشود. علاقه به رشته ״زشكى، در اين مطالعه جهارمين عامل مؤثر بر انتخاب رشته دانشجويان بود. در مطالعات Molnar و همكاران [Yr Mukhtar F و همكاران [צr]، علاقه شخصى به رشتهى يزشكى، در كنار خدمت به جامعه، جزء فاكتورهاى اصلى انتخاب رشته در دانشجويان يزشكى بوده است. در مطالعه Shakornia و همكاران، همواره ميانگين نمرات دانشجويان مقطع علوم پايه از گروههاى ديخر به طور معنى دارى بيشتر بود و رضايتمندى دانشجويان از يذيرفته شدن و تحصيل در دانشعاه در طول تحصيل، به طور معنى دارى به تدريج كاهش داشت [1/]]. يافتههاى يك مطالعه دركرواسى نيز نشان داد كه علاقه دانشجويان سال آخر يزشكى به طور معنىدارى كاهش يافته است [11]]. در مطالعهى Adib و همكاران، دانشجويان سال بالاتر، انخيزه تحصيلى كمترى نسبت به دانشجويان سال پايينتر داشتند [rT]]. علاقه به رشته انتخابى مى تواند موجب پيشرفت در كار و ارتقاى علمى شود و بر رضايتمندى شغلى تأثيركذار است [rr] و يا بر عكس بىعلاقكى منجر به ناميدى از ادامه تحصيل و افت عملكرد تحصيلى مىشود. كم شدن علاقه به
بيشترين معيار انتخاب شغل در بين دانشجويان يزشكى بود. [ [ץ]. در مطالعهى Powell A و همكاران، بيشترين انخيزه، نوع دوستى بوده است كه البته آنها نتوانسته بودند اين عامل را از اعتبار، يول و موفقيت جدا كنند. [^rا]. در مطالعهى Hassanbeigi و همكاران, به اين نتيجه رسيدند كه انخَيزهاى معنوى و عوامل مرتبط با رشد روانى اجتماعى، دجار آسيب كمترى شدهاند. همجنين در بين انخَيزهاى معنوى، عامل كمك به ديخران، كمترين آسيب را متحمل شده است [؟T]. كه از اين نظر با مطالعه حاضر همسو مىباشد. همجنين نتايج نشان داد نقش عامل انخيزه شخصى و خدمت به جامعه در هر دو مرحله در دخترها از يسرها به طور معنى دارى بيشتر است، اما در مطالعهاى كه توسط Shakornia تأثير كذارى بر اين عامل نداشت. طبق نتايج مطالعهى حاضر، نقش خانواده و دوستان، سومين عامل مؤثر بر انتخاب رشته دانشجويان يزشكى بوده است. در مطالعهى Nejat و همكاران، شناخت بسيارى از دانشجويان به هنغام انتخاب رشته يزشكى ناكامل است و تحت تأثير عواملى جون فشار اطرافيان يا مقام و منزلت يزشك در جامعه مىباشد [.ץ]. در مطالعات Rabani در اصفهان و Memarpour در شيراز، نقش والدين و دوستان در انتخاب رشته، كمترين اهميت را داشته است [بr-1؟]. طبق نتايج اين مطالعه در دانشجويان با تحصيلات مادر دكترا و بالاتر نسبت به ساير دانشجويان نقش خانواده و دوستان از اهميت بيشترى برخوردار بود. اما در مطالعه Nejat 
كه بين ادراى از عدالت آموزشى و اشتياق تحصيلى رابطه وجود دارد و رعايت اصول سازمانى همجِون برابرى در تخصيص امكانات و دستاوردها، برنامه و مسئوليتهاى آموزشى، ادب و احترام در برقرارى ارتباط با دانشجويان، زمينهى ييامدهاى آموزشى مطلوب و اشتياق تحصيلى را

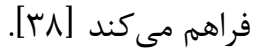
از آنجا كه نتايج به دست آمده, تنها قابل كاربرد در جامعه آمارى بزوهش مىباشد و نمىتوان آن را به جامعه آمارى ديخرى تعميم داد، پِيشنهاد مى گردد نظاير جنين مطالعاتى در ساير جامعههاى آمارى با حجم نمونه بزركتر انجام شود تا جنبه كاربردىترى داشته باشد. همزجنين اين مطالعه در همين جامعه آمارى مىتواند هر سال انجام شود تا ميزان تغيير در انخيزه دانشجويان طى مدت جندين سال و تأثير تصميمات و سياست كذارىهاى مختلف بر انخيزه آنها بررسى شود. نكته اي كه اين مطالعه را از ساير مطالعات انجام شده متمايز مى كند اين است كه ساير مطالعات همكى مقطعى بودند، اما اين مطالعه طى دو مرحله و به فاصله يك سال انجام شد و ميزان تغييرات انغَيزه در طول اين مدت نيز مورد بررسى قرار كرفت.

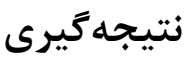
نتايج اين مطالعه نشان داد مهمترين دلايل انتخاب رشته يزشكى، به ترتيب شامل: درآمد مناسب و منزلت اجتماعى، انكَيزه شخصى و خدمت به جامعه و نقش خانواده و دوستان مىباشد و علاقه به رشته يزشكى و نقش موقعيت علمى دانشَاه اهميت كمترى دارند، همرجنين پِ از كذشت يك سال تحصيلى نمره عامل علاقه به رشته يزشكى و نقش
رشته يزشكى در طول مدت تحصيل مىتواند ناشى از عدم شناخت كافى از اين رشته در حين انتخاب رشته باشد كه مىتوان با افزايش شناخت صحيح دانشآموزان از رشتههاى تحصيلى در هنگام انتخاب رشته از اين مسئله جلوكيرى كرد.در مطالعهى Nejat و همكاران، با بالا رفتن سن شركت كنندكان، ارزيابى آنان از آينده شغلى يزشكى بصورت معنىدارى تغيير مى كند، بدين صورت كه با بالا رفتن سن، امكان ادامه تحصيل و يافتن شغل يا درآمد مناسب و در مكان مناسب، مشكلتر از ساير رشتهها تعيين شده است و شناخت بالاترى نسبت به آينده شغلى ييدا مىكنند [•r]]. در مطالعهى Daniel Pagin و همكاران، نتيجه كرفتند تفاوتى بين انخيزهى دانشجويان سال اول، دوم، جهارم و ششم ديده نشد كه مىتواند مطرح كنندهى ثابت بودن انكَيزه دانشجويان در طول دوران تحصيل باشد كه البته به مطالعات طولى نياز دارد تا اين مطلب تأييد شود [هـ]]. در مطالعه Prka و همكاران [عץ] و در مطالعه Petrie و همكاران [rv] نتيجه كرفتند كه علايق دانشجويان به طور معنىدارى در دانشگاه تغيير نكرده است كه نتايج اين مطالعات، با

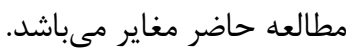
براساس نتايج به دست آمده، موقعيت علمى-آموزشى دانشگاه، ينجمين عامل مؤثر بر انتخاب رشته دانشجويان بوده است. در مطالعه Hassanbeigi و همكاران در يزد، به اين نتيجه رسيدند كه نارضايتى دانشجويان از خدمات و امكانات آموزشى دانشكاه و عدم دسترسى به امكانات رفاهى، منجر به كمبود انكَيزهى قابل توجه دانشجويان مىشود [rq]. در مطالعهى Pourfatemi و همكاران، نتيجه كرفتند 
^• بررسى دلايل انتخاب رشته يزشكى و ميزان تغيير در انكيزه دانشجويان متعاقب يك سال تحصيلى ...

علاقه دانشجويان به رشته ڤزشكى كاسته مىشود كه طبيعتاً

مىتواند باعث افت عملكرد آنها شود و بايد به عنوان زنت

خطرى براى مسئولين بهداشت و درمان در نظر گرفته شود.

$$
\text { تشكر و قدردانى }
$$

بر خود لازم مى دانيم از كليه دانشجويان يزشكى دانشگاه علوم يزشكى رفسنجان كه در اين مطالعه شركت داشتند، قدردانى
موقعيت علمى دانشگاه به صورت معنى دارى كاهش ييدا كرده بود. همرجنين نتايج مقايسه بين ورودىهاى مختلف در هر مرحله نشان داد با افزايش سنوات تحصيل و بالاتر رفتن مقطع تحصيلى از علاقه به رشته يزشكى نيز كم مىشود كه بايد به عنوان هشدارى براى آموزش يزشكى و مسئولين سلامت تلقى گردد. همرجنين درآمد مناسب و منزلت اجتماعى، مهمترين انخَيزه انتخاب رشته در بين دانشجويان يزشكى مىباشد و با افزايش سنوات تحصيل از انخيزه و

\section{References}

[1] Hughes R, curphy g, ginnett r. Leadership enhancing the lesson of experience. 3 ed1999.

[2] Kazemzadeh Rb, Hashemi MS. A study of job motivation factors in the organization based on the herzberg theory and proposing two measurement models for motivation and hygiene factors: a case study of the oil and energy industrial development company. 2009

[3] Dussault G, Dubois C-A. Human resources for health policies: a critical component in health policies. Human Resources for Health 2003; 1(1): 1.

[4] Kavosi Z, Mirzaie M. Assessment of the Required Manpower for Shiraz University of Medical Sciences hospitals based on Ministry of Health and Medical Education Method, 2012. Journal of Health Management and Informatics 2014; 2(1): 5-8.
[5] McManus IC, Livingston G, Katona C. The attractions of medicine: the generic motivations of medical school applicants in relation to demography, personality and achievement. BMC Med Educ 2006; 6: 11 .

[6] Cook DA, Artino Jr AR. Motivation to learn: an overview of contemporary theories. Medical Education 2016; 50(10): 997-1014.

[7] Kusurkar R, Ten Cate TJ, Van Asperen M, Croiset G. Motivation as an independent and a dependent variable in medical education: a review of the literature. Medical teacher 2011; 33(5): e242-e62

[8] Bateman, A.Brown, D., Pedder, J. [2000]. Introduction to psychotherapy: an outline of psychodynamic principles and practice. [3rd ed.]. London: Routledge, 28-29. 
[9] Pagnin D, De Queiroz V, Oliveira Filho MAD, Gonzalez NVA, Salgado AET, Oliveira BCE, et al. Burnout and career choice motivation in medical students. Medical teacher 2013; 35(5): 388-94.

[10] Hamedi Rad F, Ghaffari T, Hoshyar E. Motivations for choosing field of study among medical and dental students of Tabriz University of Medical Sciences, Tabriz, Iran. Research and Development in Medical Education 2014; 3(1): 25.

[11] Gąsiorowski J, Rudowicz E, Safranow K. Motivation towards medical career choice and future career plans of Polish medical students. Advances in health sciences education 2015; 20(3): 709-25

[12] Shakornia A, Khajeh Ali N, Bagheri A, Bijanzadeh M. Factors affecting medical major selection and the extent of changes in students' motivation during their study in Ahvaz Jundishapur University of Medical Sciences. Iranian Journal of Medical Education 2016; 16: 189-99.

[13] Puljak L, Kraljevic JB, Latas VB, Sapunar D. Demographics and motives of medical school applicants in Croatia. Medical Teacher 2007; 29(8): e227-e34.

[14] Iravani K, Amini M, Doostkam A. A survey of medical students' attitude toward medicine and it's future in Jahrom Medical University [basic and clinical stages]. Iranian Journal of Medical Education 2002; 2: 28-9.
[15] Ghaderi R, Dastjerdi R, Sorush Z, Mouhebati M. Influential Factors in Medical StudentsAttitudes towards Studying Medicine in 2002. Iranian Journal of Medical Education 2003; 3(2): 47-55.

[16]. Mohammadi Roozbahani K, Taromi A. "Applicants, Motivational Factors for University Admission." Quarterly Journal of Research and Planning in Higher Education 11.3 [2006]: 103-125.

[17] Solas, J. [1996]. Why choose psychology as a carrer? Journal of Australian Psychologists 31(2): 144-46

[18] Berger, K.S.[2001]. The developing person through the life span. [5rd ed.]. New york: Worth, 499-505.

[19] Hirsch G. [2001]. Helping college students succed: a Model for effective Intervention. [First ed.] Philadelphia: Brunner - Routledge, 85-88.

[20]Crossley ML, Mubarik A. A comparative investigation of dental and medical student's motivation towards career choice. $B r$ Dent $J$ 2002; 193(8): 471-3. doi:10.1038/sj.bdj.4801599

[21] Dikici MF, Yaris F, Topsever P, Filiz TM, Gurel FS, Cubukcu M. Factors Affecting Choice of Specialty Among First-year Medical Students of Four Universities in Different Regions of Turkey. Croat Med J 2008; 49(3): 415-20.

[22] Adib-Hajbaghery M, Arabi Matin Abadi MJ, Ghadirzadeh Z, Moujoodi H, Mehdiansaripour M. [Interest in the Field of Study and Affecting Factors: The Viewpoint of Students of Kashan University of 


\section{•. بررسى دلايل انتخاب رشته يزشكى و ميزان تغيير در انگيزه دانشجويان متعاقب يك سال تحصيلى ..}

Medical Sciences]. Iranian Journal of Medical

Education 2017; 17: 24-34

[23] Vaglum P, Wiers-Jenssen J, Ekeberg O. Motivation for medical school: the relationship to gender and specialty preferences in a nationwide sample. Med Educ 1999; 33(4): 236-42.

[24] Molnár R, Nyári T, Hazag A, Csinády A, Molnár P. Career choice motivations of medical students and some characteristics of the decision process in Hungary. Central European Journal of Medicine 2008; 3(4): 494-502.

[25] Puljak L, Brnjas Kraljevic J, Barac Latas V, Sapunar D. Demographics and motives of medical school applicants in Croatia. Med Teach 2007; 29(8): e22734.

[26] Mukhtar F, Daud S, Hashmi NR, Masood A, Bhatti A. Selection of medical profession by first year medical students. Professional Med J 2009; 16: 55663.

[27] Fields SA, Toffler WL. Hopes and concerns of a firstyear medical school class. Med Educ 1993;27[2]:124129. doi:10.1111/j.1365-2923. 1993. tb00242.x

[28] Powell A., Boakes J., Slater, P., What motivates medical students: How they see themselves and their profession, Med Educ 1987; 21: 176-82.

[29] Hassanbeigi AF, Askari J. A study of the most important risk factors of motivational deficiencies in university students. Procedia Social and Behavioral Sciences 2010; 5: 1972-6.

[30] Nejat S, Emami Razavi H, Rashidian A, Yazdani S, Majdzadeh R. [The Motives of Medical Students in Tehran University for Choosing Medicine Field and their Outlooks for their Profession: Qualitative versus Quantitative Approach]. Strides in Development of Medical Education 2006; 3(1): 1-10. [Farsi]

[31] Rabani R, Rabiei K. [Evaluation of Major Selection and its Impact on Educational Satisfaction among Isfahan University Students]. Qurterly Journal of Research and Planning in Higher Education 2011; 17(2): 99-120. [Farsi]

[32] Memarpour M, Bazrafcan L, Mosavi E, Vossoghi M. [Factors Influencing Dental Students' Choice of Discipline]. Iranian Journal of Medical Education 2013; 13 (4): 260-69. [Farsi]

[33] Izadi S, Jouybari L, Behnampoor N, Taghavi A, Baiky F. Academic motivation and associated factors of the Golestan University of Medical Sciences. DSME 2014; 1 (2) :44-50.

[34] Hyppölä H, Kumpusalo E, Neittaanmäki L, et al. Becoming a doctor--was it the wrong career choice? Soc Sci Med 1998; 47(9): 1383-87

[35] Pagnin D, De Queiroz V, Oliveira Filho MAD, Gonzalez NVA, Salgado AET, Oliveira BCE, et al. Burnout and career choice motivation in medical students. Medical Teacher 2013; 35(5): 388-94. 
[36] Prka M, Danic A, Glavas E, What do medical students want from their professional and privat life, CMJ 2002, 1, 80-83

[37] Petrie KJ, White GR, Cameron LD, Collins JP, Photographic memory, money, and liposuction: survey of medical students' wish lists, BMJ 1999; 319: 1593-5.
[38] Pourfatemi A, Momenimahmouei H. The relationship between perceived educational justice and awareness of the future of career with academic enthusiasm among the students of a University of Medical Sciences. JMED 2019; 13 (4): $332-44$. 
VIT برسى دلايل انتخاب رشته يزشكى و ميزان تغيير در انغيزه دانشجو يان متعاقب يك سال تحصيلى ...

\title{
The Reasons for Medical Field Selection and the Extent of Changes in Students' Motivation During one Academic Year (2018-2019) in Rafsanjan University of Medical Sciences: A Descriptive Study
}

\author{
K. Damghany', H. Ahmadinia ${ }^{r}, \underline{\text { M.Rezaeian }}{ }^{r}$
}

Received: 18/10/2020 Sent for Revision: 07/11/2020 Received Revised Manuscript: 16/05/2021 Accepted: 25/05/2021

Background and Objectives: Medical students' motivations for selecting the medicine has a key role in their future performance as a health care worker.The purpose of this study was to determine the reasons for medical field selection and the extent of changes in students' motivation following one academic year (2018-2019) in Rafsanjan University of Medical Sciences

Material and Methods: In this descriptive study done in two stages and during one year, the statistical population included all the medical students of Rafsanjan University of Medical Sciences who were studying in both the academic years of 2018-2019 and 2019-2020. About 430 people entered the study through census. The data collection tool was a questionnaire. Data were analyzed using chi-square test, independent samples t-test, and oneway analysis of variance.

Results: During one year, the factors of interest in medicine $(p=0.010)$ and the academic ranking of the university $(p<0.001)$ were significantly reduced. But changes in other factors were not significant $(p>0.05)$. The factor of individual motivation and serving the society in both stages was significantly higher in the female sudents $(\mathrm{p}<0.001)$.

Conclusion: Adequate income and social status are the most important motivations for choosing medicine among medical students. In the higher levels of education, the motivation and interest in studying medical fields decreases, which can naturally lead to a decline in their performance and should be taken as a warning for health officials

Key words: Medical student, Motivation, Major selection, Rafsanjan.

Funding: This study did not have any funds.

Conflict of interest: None declared.

Ethical approval: The Ethics Committee of Rafsanjan University of Medical Sciences approved the study (IR.RUMS.REC.1397.249).

How to cite this article: Damghany K, Ahmadinia H, Rezaeian M. The Reasons for Medical Field Selection and the Extent of Changes in Students' Motivation During one Academic Year (2018-2019) in Rafsanjan University of Medical Sciences: A Descriptive Study. J Rafsanjan Univ Med Sci 2021; 20 (6): 697-712. [Farsi]

1- Medical Student, Rafsanjan University of Medical Sciences, Rafsanjan, Iran, ORCID:0000000269246979

2 - PhD in Biostatistics, Dept. of Social Epidemiology and Biostatistics, Medical School, Rafsanjan University of Medical Sciences, Rafsanjan, Iran, ORCID: 0000000270101726

3- Prof., Dept. of Social Epidemiology and Biostatistics, Rafsanjan University of Medical Sciences, Rafsanjan, Iran, ORCID:0000000330700166

(Corresponding Author) Tel: (034) 31315123 , Fax :(034) 31315123 , E-mail: moeygmr2@yahoo.co.uk

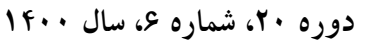

مجله دانشگاه علوم يزشكى رفسنجان 